\title{
Development and validation of a new and economical stability indicating RP-HPLC method for cefixime trihydrate
}

\author{
Ceema Mathew ${ }^{1,2, *}$, Bellamkonda Swathi', Makula Ajitha², Puvvadi Sathesh Babu'

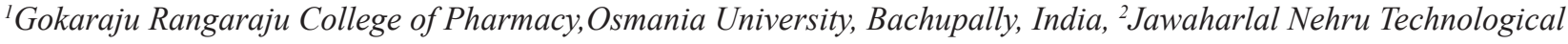 \\ University, Hyderabad, India
}

\begin{abstract}
The present work describes the development of a new high performance liquid chromatographic (HPLC) method for the determination of Cefixime trihydrate under different stress conditons as specified by ICH. For the analysis, a Phenomenex $(250 \times 4.6 \mathrm{~mm}, 5 \mu \mathrm{m}$ particle size $)$ ODS column and a SPD 20 A UV detector at $289 \mathrm{~nm}$ was used. The selected mobile phase was $10 \mathrm{mM}$ disodium hydrogen phosphate (with $0.5 \%$ TEA, pH adjusted to 6.3 with OPA) and methanol in the ratio of 75:25 (v/v) in isocratic mode at a flow rate of $1 \mathrm{~mL} \cdot \mathrm{min}^{-1}$. The linear regression analysis data for the calibration plots showed good linear relationship with $\mathrm{r}^{2}=0.9997$ in the concentration range of 5-100 $\mu \mathrm{g} \cdot \mathrm{mL}^{-1}$. The stress degradation was performed using acid, alkali, water, hydrogen peroxide and uv light.
\end{abstract}

Uniterms: High Performance Liquid Chromatography/quantitative analysis. Degradation. Stabilityindicating. Cefixime trihydrate/determination.

\begin{abstract}
O presente trabalho descreve o desenvolvimento de um novo alta performance cromatografia líquida (HPLC) método para a determinação de cefixima tri-estresse sob diferentes condições, conforme especificado pelo ICH. Para a análise, a Phenomenex (250 x 4,6 mm, $5 \mu \mathrm{m}$ de granulometria) ODS coluna e a SPD 20 um detector de UV em $289 \mathrm{~nm}$ foi utilizado. A fase móvel selecionado foi de $10 \mathrm{mM}$ hidrogenofosfato dissódico (com 0,5\% TEA, o pH ajustado para 6,3 com OPA) e de metanol em razão de 75:25 (v/v) no modo isocrático com uma taxa de fluxo de $1 \mathrm{~mL} \cdot \mathrm{min}^{-1}$. A análise de regressão linear para dados da calibração parcelas apresentaram boa relação linear com $r^{2}=0,9997$ no intervalo de concentração de cerca de $5100 \mu \mathrm{g} . \mathrm{mL}^{-1}$. Degradação do estresse foi realizado utilizando um ácido, alcalino, a água, o peróxido de hidrogênio e luz uv.
\end{abstract}

Unitermos: Cromatografia líquida de alto desempenho/análise quantitativa. Degradação. Indicador de estabilidade. Cefixima triidratada/determinação.

\section{INTRODUCTION}

Cefixime trihydrate (Chemical structure is given in Figure I) [(6R,7R)-7-(2-(2-amino-4-thiazolyl) glyoxylamido]-8-oxo-3-vinyl-5-thia-1-azabicyclo[4.2.0] oct-2-ene-2-carboxylic acid, 72-(Z)-[O-(carboxymethyl) oxime] is an orally absorbed third generation cephalosporin antibiotic that was approved by the U.S. Food and Drug Administration in 1997 for the treatment of mild to moderate bacterial infections. It has a broad antibacterial spectrum against various Gram-positive and Gramnegative bacteria, including Haemophilus influenzae,

*Correspondence: Ceema Mathew. Gokaraju Rangaraju College of Pharmacy. Bachupally, Hyderabad-90, India. E-mail: nirujose@gmail.com
Neisseria gonorrhoeae, Escherichia coli and Klebsiella pneumoniae resistant to ampicillin, cephalexin, cefaclor and trimethoprim - sulfamethoxazole. It is used for the treatment of susceptible infections, including gonorrhea, otitis media, pharyngitis, lower respiratory-tract infections such as bronchitis and urinary-tract infections (Brogden, Richards, 1989; Sweetman, 2002; Zahra Talebpour et al., 2013).

Cefixime degrades under storage conditions (temperature and relative humidity) and its degradation products can cause undesirable side effects in patients (Kitamura et al., 1989; Kitamura et al., 1990). A detailed literature survey has shown that cefixime has been studied by various analytical methods like spectrophotometric (El-Walily et al., 2002; Attimarad et al., 2011), fluorimetric 
(Bebawy, El-Kelani, Fattah, 2003), voltammetric (Golcu, Dogan, Ozkan, 2005; Jain et al., 2010), HPLC (Dhoka, Sandage, Dumbre, 2010; Arshad et al., 2009; Khan et al., 2008; Shah, Pundarikakshudu, 2006; Manna, Valvo, 2004; Meng et al., 2005; Gonzalez-Hernandez et al., 2001; Khandagle, 2011), and HPTLC (Singh, Maheshwari, 2010; Eric-Jovanovic et al., 1998; Pawar et al., 2010).

Although different analytical methods are available, a more economical stability indicating analytical method is developed for cefixime. We have forcefully degraded the drug (standard) under different stress conditions and developed an HPLC method that can differentiate the pure drug from its degradants. In an attempt to practice green chemistry and also to develop a cost effective analytical method, we have tried to minimise the use of organic solvent (ie methanol to $25 \%$ ).

The International Conference on Harmonization (ICH) guideline entitled "Stability Testing of New Drug Substances and Products" requires that stress testing be carried out to elucidate the inherent stability characteristics of the active substance (ICH, 2005). Acidic, alkaline, oxidative, and photolytic stabilities are required. An ideal stability indicating method is the one that quantifies the standard drug alone and also resolves it from its degradation products (Bakshi, Singh, 2002).

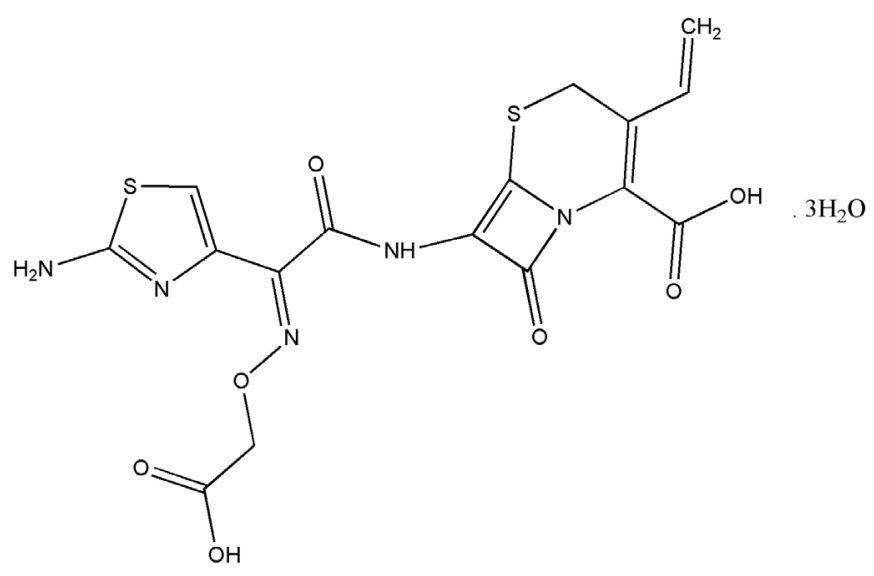

FIGURE 1 - Structure of cefixime trihydrate (CEF).

\section{EXPERIMENTAL}

\section{Material and reagents}

Cefixime trihydrate (CEF) API was available as gift sample from Dr.Reddys Lab, Hyderabad. Methanol, disodium hydrogen phosphate and potassium dihydrogen phosphate were purchased from S.D Fine Chemicals (Mumbai, India) and were of HPLC grade. Hydrochloric acid, sodium hydroxide, hydrogen peroxide and orthophosphoric acid were purchased from S.D Fine Chemicals (Mumbai, India) and were of A.R grade. HPLC grade water was prepared in house by the triple distillation of water followed by filtration through filter paper of $0.45 \mu \mathrm{m}$ pore size. The standard solution of $100 \mu \mathrm{g} / \mathrm{mL}$, prepared from the API was used for injection onto the HPLC column. The dosage forms used were Cefigip and Taxim-O each of which contained $200 \mathrm{mg}$ per tablet.

\section{HPLC instrumentation and chromatographic conditions}

The HPLC system consists of a Shimadzu LC 20 AD binary pump and SPD 20 A UV detector. The column consists of Phenomenex ( $250 \mathrm{~mm}$ length, $4.6 \mathrm{~mm}$ internal diameter, $5 \mu \mathrm{m}$ particle size) Luna ODS column. LC Solution software was used for data acquisition. Sample injection was done by Rheodyne manual Injector. For the analysis, isocratic mode was selected and the mobile phase is a mixture of methanol and phosphate buffer ( $\mathrm{pH}$ 6.8) in the ratio of 25:75. Phosphate buffer is prepared with $5.04 \mathrm{~g}$ of disodium hydrogen phosphate and $3.01 \mathrm{~g}$ potassium dihydrogen phosphate dissolved in $1000 \mathrm{~mL}$ of triple distilled water. The mobile phase was pumped at a rate of $1.0 \mathrm{~mL} / \mathrm{min}$ at room temp. $20 \mu \mathrm{L}$ of sample was injected each time using rheodyne manual injector. For the detection,the wavelength was set at $298 \mathrm{~nm}$ and the peak areas integration was performed using LC solution software.

\section{Methodology for stress testing}

Specificity of the developed method was proved by stress degradation studies where the drug was intentionally degraded under different stress conditions as specified by $\mathrm{ICH}$.

Stress studies were performed by subjecting CEF standard solutions to forced degradation by acidic $(1 \mathrm{~N} \mathrm{HCl})$, basic $(0.1 \mathrm{~N} \mathrm{NaOH})$, neutral hydrolytic (purified water) and oxidative degradation $\left(3 \% \mathrm{H}_{2} \mathrm{O}_{2}\right)$ conditions. A stock solution of $1 \mathrm{mg} / \mathrm{mL}$ was prepared in methanol. $2 \mathrm{~mL}$ of solution was treated with $2 \mathrm{~mL}$ of each of the reagent separately and all the mixtures were kept away from light to exclude the possibility of any photolytic degradation. The acidic mixture was kept for $24 \mathrm{~h}$ after which it was neutralised with $1 \mathrm{~N} \mathrm{NaOH}$ solution and an aliquot was diluted with the mobile phase so as to yield $100 \mu \mathrm{g} / \mathrm{mL}$. For the alkaline mixture, prepared with equal volume of $0.1 \mathrm{~N} \mathrm{NaOH}$, it was observed that the drug peak disappeared after $30 \mathrm{~min}$, along with many extra peaks indicating that the alkaline degradation was vigorous. Hence the mixture 
was kept for 10 min after which it was neutralized with $0.1 \mathrm{~N} \mathrm{HCl}$ and an aliquot was diluted with the mobile phase to yield $100 \mu \mathrm{g} / \mathrm{mL}$. Neutral degradation was done in an identical manner using purified water and the mixture was kept for $48 \mathrm{~h}$ for the possible degradation, but excluding any neutralization procedure. For oxidative degradation the stock solution was treated with equal volume of $3 \% \mathrm{H}_{2} \mathrm{O}_{2}$ solution kept for $2 \mathrm{~h}$ at room temp after which $100 \mu \mathrm{g} / \mathrm{mL}$ solution was prepared from that for injection.

Photolytic degradation was performed on $100 \mu \mathrm{g} / \mathrm{mL}$ solution, prepared from dry powder exposed to short UV radiations (wavelength $=254 \mathrm{~nm}$ ) for a period of $24 \mathrm{~h}$.

\section{Preparation of solutions for injection}

$10 \mathrm{mg}$ of the reference substance was dissolved in $10 \mathrm{~mL}$ of methanol $(1000 \mu \mathrm{g} / \mathrm{mL})$. The working standard solution $(100 \mu \mathrm{g} / \mathrm{mL})$ was prepared by dilution of the stock solution using mobile phase.

A quantity of tablet powder equivalent to $25 \mathrm{mg}$ of CEF was transferred to a $25 \mathrm{~mL}$ volumetric flask and added $10 \mathrm{~mL}$ of methanol, kept in an ultrasonic bath for $10 \mathrm{~min}$ and made upto the volume with methanol and filtered.

\section{Validation study}

The developed method was validated as per ICH guidelines with respect to the following parameters: accuracy, precision, LOD, LOQ, specificity, robustness, stability and system suitability. All the solutions required for validation data were prepared with cefixime standard.

\section{Linearity}

For testing linearity seven calibration standards were prepared in the range of 5 to $100 \mu \mathrm{g} / \mathrm{mL}(5,10,20,40$, 60,80 and $100 \mu \mathrm{g} / \mathrm{mL}$ ). Standard curve was obtained by plotting peak area against concentration and the evaluation of linearity was done by linear regression analysis using least square method.

\section{Limit of detection and limit of quantitation}

Limit of detection (LOD) and limit of quantitation (LOQ) were estimated at a signal to noise ratio of $3: 1$ and 10:1 respectively by injecting a series of dilute solutions of known concentration.

\section{Robustness}

Experimental conditions were deliberately altered, in order to determine the robustness. From the different experimental conditions such as flow rate $(1.0 \mathrm{~mL} / \mathrm{min})$, lambda max (298 nm) and percentage of methanol (25), each selected factor was changed at three levels $(-1,0,+1)$. Each factor was changed at a time to study the impact of the change in the experimental conditions on the assay results. Change in the in the peak area and the retention time were noted at for each change in the analytical parameters.

\section{Stability of sample solution}

Sample solution was prepared and analysed by the HPLC instrument using fresh mobile phase at different time intervals $(0 \mathrm{~h}, 8 \mathrm{~h}$ and $24 \mathrm{~h})$.

\section{Accuracy}

Accuracy of the developed method was assessed in triplicate at three concentrations $(40,60$ and $80 \mu \mathrm{g} / \mathrm{mL})$. The percentage recovery was calculated from the linear regression equation obtained in the linearity studies.

\section{Precision}

The precision of the analytical method was evaluated by the determination of the repeatability of the method (intra day precision) and intermediate precision (inter day precision) of the sample solutions. Repeatability was calculated by assaying six samples prepared on the same day. Intermediate precision was calculated by assaying 3 days. The relative standard deviation of the area of peaks was calculated.

\section{RESULTS AND DISCUSSION}

\section{UV spectral analysis}

In order to identify the absorption peaks in the UV region, a scan of cefixime trihydrate was taken in methanolic solution of phosphate buffer (25:75), which indicated that $289 \mathrm{~nm}$ was the absorption maximum $\left(\lambda_{\max }\right)$.

\section{Optimization of chromatographic conditions}

To analyze cefixime trihydrate together with its possible degradation products, reverse phase LC in combination with UV detector was developed, optimized and validated. After trials with different mobile phase compositions, a satisfactory separation for the drug and 
TABLE I - Assay for tablet formulations

\begin{tabular}{lccccc}
\hline S.NO. & Formulation & $\begin{array}{c}\text { Labelled Claim } \\
(\mathbf{m g})\end{array}$ & $\begin{array}{c}\text { Amount found (mg) } \\
\text { Mean } \pm \text { SD }\end{array}$ & Assay (\%) & \%RSD \\
\hline 1 & Cefigip & 200 & $202.379 \pm 1.983$ & 101.19 & 0.984 \\
2 & Taxim-O & 200 & $203.773 \pm 1.657$ & 101.89 & 0.813 \\
\hline
\end{tabular}

its degradation products were obtained with mobile phase consisting of $10 \mathrm{mM}$ disodium hydrogen phosphate with $0.5 \%$ TEA (pH adjusted to 6.3 with OPA) and methanol in the ratio of 75:25(v/v), pumped at a flow rate of $1 \mathrm{~mL} / \mathrm{min}$. The detection was carried out at $289 \mathrm{~nm}$ and the retention time was found to be $6.81 \mathrm{~min}$.

\section{Calibration plot for cefixime trihydrate}

A linear calibration plot for the method was obtained over the calibration range of $5-100 \mu \mathrm{g} / \mathrm{ml}$ at a wavelength of $289 \mathrm{~nm}$. The equation of the regression line was found to be $y=84923 x+36508$ with a correlation coefficient of 0.9997.The results showed that an excellent correlation exists between the peak area and concentration of the analyte.

\section{Analysis of the marketed formulations}

The proposed method was evaluated by the assay of commercially available tablets (formulation-I and formulation- II) containing cefixime trihydrate $(200 \mathrm{mg})$. The results obtained for cefixime trihydrate was compared with the corresponding labeled amounts and reported in Table I. The amount of cefixime trihydrate found in formulation - I (Cefigip) and formulation II (Taxim O) was $202.37 \mathrm{mg}$ and $203.77 \mathrm{mg}$ respectively. These amounts are within the limits. For both formulation-I and formulation- II the $\%$ RSD was less than 2 , which indicated the accuracy of the proposed method.

\section{Stress degradation studies}

Cefixime trihydrate was found to degrade under acidic condition $(1 \mathrm{~N} \mathrm{HCl})$. The degradation reaction was more intense and quicker in alkaline condition because the std solution resulted from the alkaline mixture, prepared with an equal volume of $0.1 \mathrm{~N} \mathrm{NaOH}$, the drug peak disappeared after $30 \mathrm{~min}$, along with many extra peaks. Hence, the reaction time was reduced to $10 \mathrm{~min}$. In the absence of acid or base also, it undergoes hydrolysis, which is revealed by the presence of extra peaks. Upon treatment with $3 \% \mathrm{v} / \mathrm{v} \mathrm{H} 2 \mathrm{O} 2$ at room temperature, it was found that the drug was degraded. Additional peaks were observed after $24 \mathrm{~h}$ exposure to UV light indicating that the drug is not photostable.

The chromatograms obtained under different stress conditions are in Figure 2. 1 to 5 and the CEF std drug peak is labelled in all chromatograms. The resolution was found to be more than 2 in all the cases.

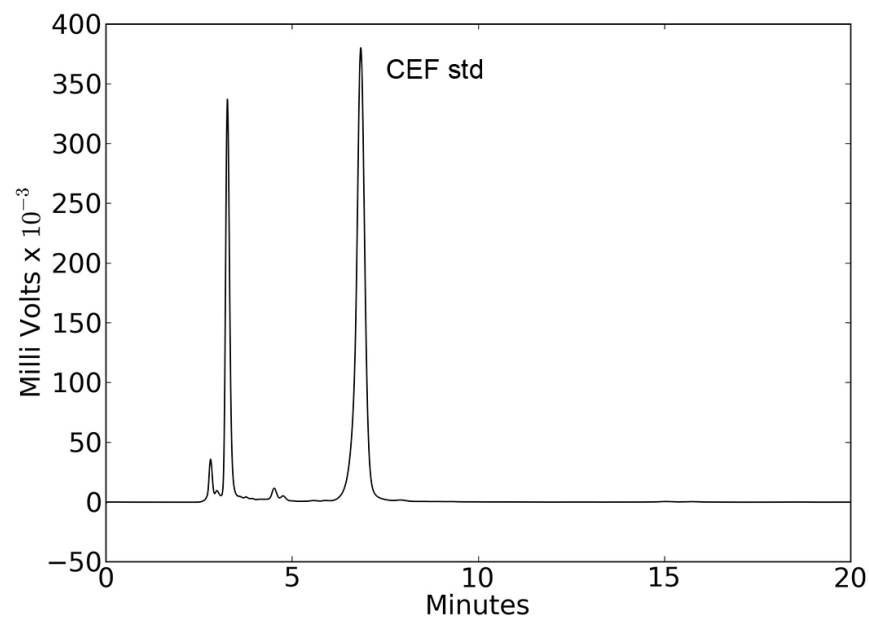

FIGURE 2-1 - Chromatogram for oxidative degradation (Rt of CEF std $=6.838$ ).

\section{Method validation}

The method was validated for all validation parameters as per ICH guidelines. The linear regression data for the calibration curve $(n=3)$ showed good linear relationship over the concentration range $5-100 \mu \mathrm{g} / \mathrm{mL}$. No significant difference was observed in the slopes of standard curves.

\section{Precision}

The repeatability (intra-day precision) of the method was determined by intra-day $(n=3)$ analysis of three standard solutions of cefixime trihydrate at the concentration of 5,20 and $40 \mu \mathrm{g} / \mathrm{mL}$. Intermediate precision was determined by the inter-day $(n=6)$ analysis of three standard solutions of cefixime trihydrate at the concentration of 5, 20 and $40 \mu \mathrm{g} / \mathrm{ml}$. The data obtained 


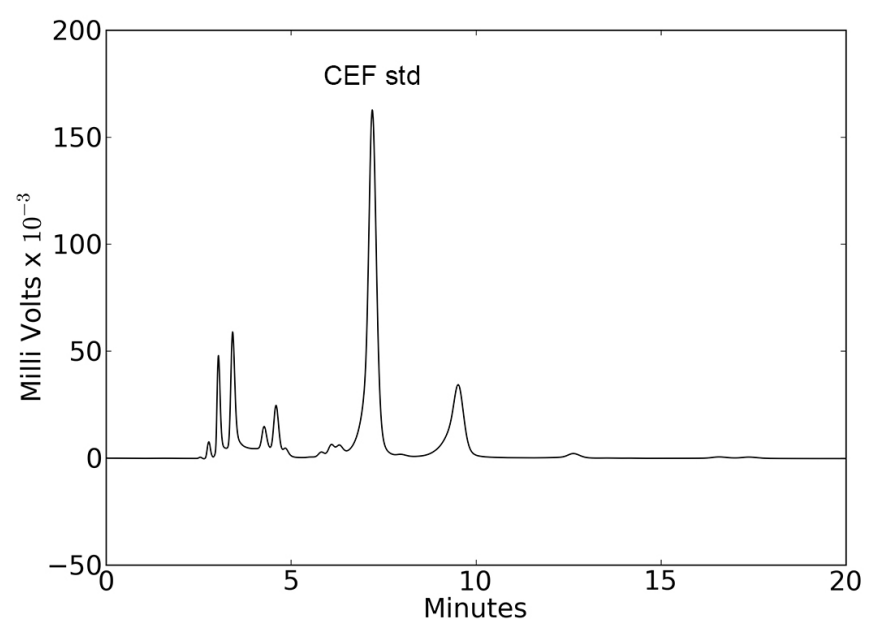

FIGURE 2-2 - Chromatogram for alkaline degradation (Rt of CEF std $=6.845)$.

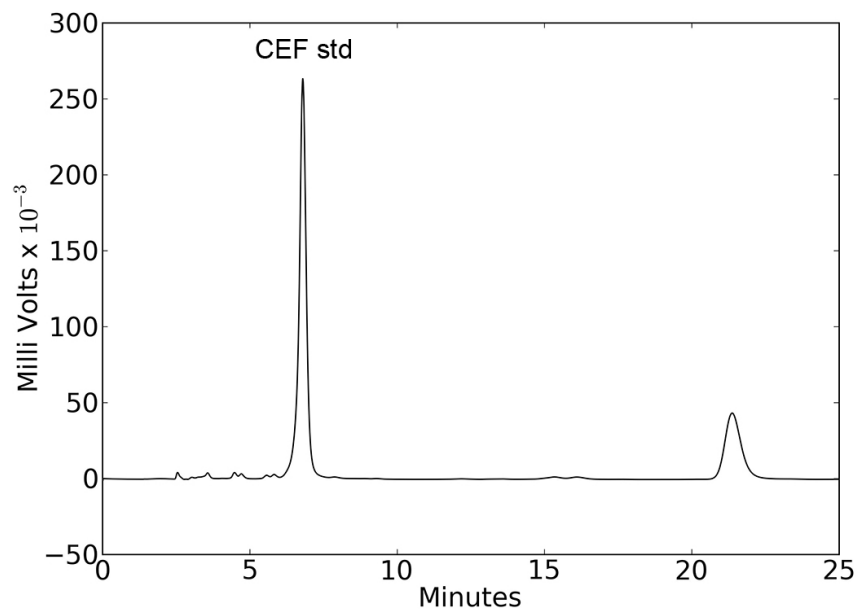

FIGURE 2-3 - Chromatogram for acidic degradation (Rt of CEF std $=6.791)$.

from precision experiments are given in Table II for intraand inter-day precision studies. The $\% \mathrm{RSD}$ values for intra-day and inter-day study were $<2.0 \%$, confirming that the method was precise.

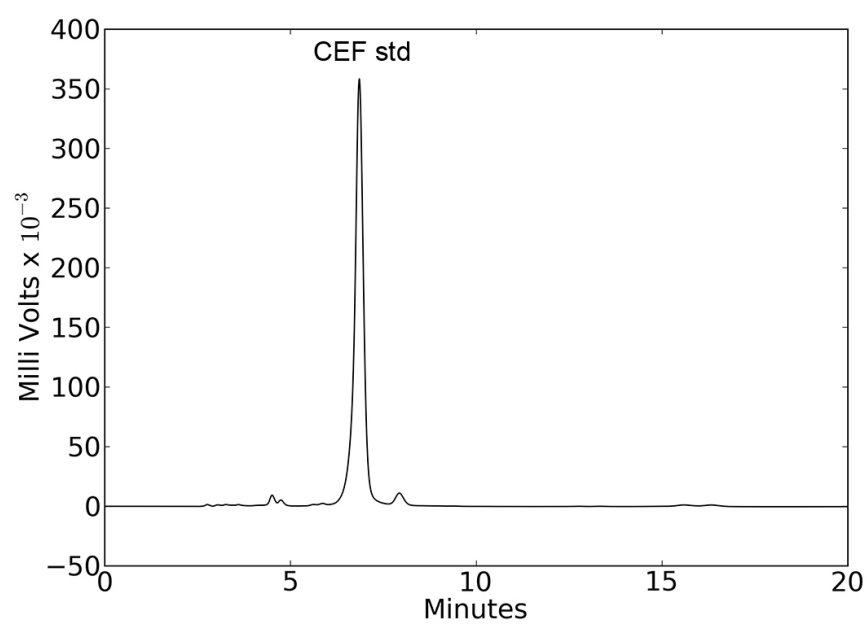

FIGURE 2-4 - Chromatogram for hydrolytic degradation (Rt of CEF std $=6.91)$.

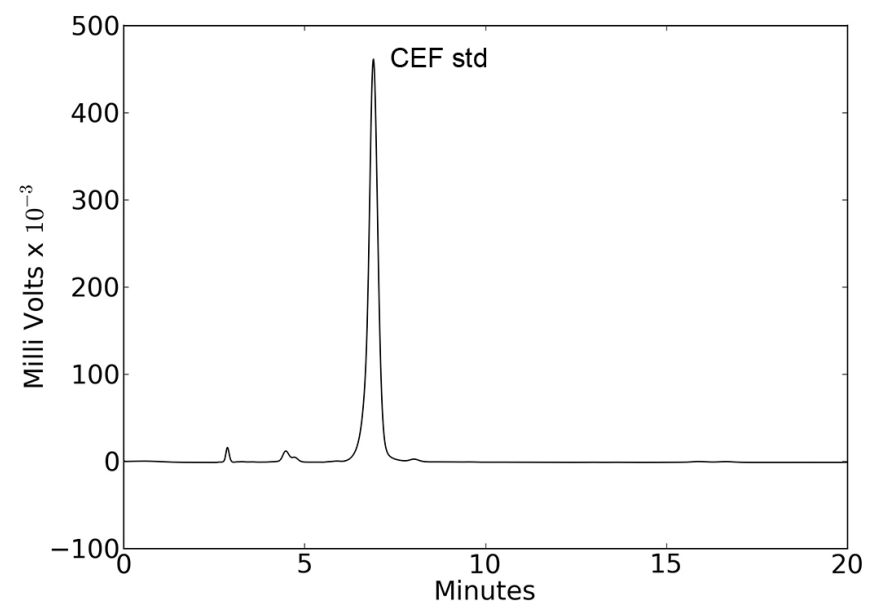

FIGURE 2-5 - Chromatogram for photolytic degradation (Rt of CEF std $=6.890)$.

\section{Accuracy (recovery studies)}

The proposed method when used for extraction and subsequent estimation of cefixime trihydrate from

TABLE II - Data for precision

\begin{tabular}{lcccccc}
\hline $\begin{array}{l}\text { Concentration } \\
(\boldsymbol{\mu} \mathbf{g} / \mathbf{m L})\end{array}$ & \multicolumn{3}{c}{ Intra-day Precision $(\mathbf{n}=\mathbf{3})$} & \multicolumn{3}{c}{ Inter-day Precision $(\mathbf{n}=\mathbf{6})$} \\
\cline { 2 - 6 } & Amount & SD & \%RSD & Amount & SD & \%RSD \\
\hline 5 & 6.029 & 0.012 & 0.200 & 6.010 & 0.023 & 0.387 \\
20 & 19.629 & 0.065 & 0.331 & 19.382 & 0.303 & 1.567 \\
40 & 39.003 & 0.465 & 1.192 & 38.837 & 0.400 & 1.029 \\
\hline
\end{tabular}

Acceptance Criteria: \% RSD should not be more than 2. 
TABLE III - Data for recovery studies

\begin{tabular}{|c|c|c|c|c|c|c|c|}
\hline Tablet & $\begin{array}{c}\text { Excess drug } \\
\text { added to } \\
\text { analyte (\%) }\end{array}$ & $\begin{array}{l}\text { Theoretical } \\
\text { content (mg) }\end{array}$ & $\begin{array}{c}\text { Amount found } \\
(\mathrm{mg})\end{array}$ & $\begin{array}{l}\text { Recovery } \\
(\%)\end{array}$ & SD & $\%$ RSD & SE \\
\hline \multirow{4}{*}{ T 1} & 0 & 20 & 20.16 & 100.785 & 0.199 & 0.987 & 0.114 \\
\hline & 80 & 36 & 36.51 & 101.416 & 0.132 & 0.362 & 0.076 \\
\hline & 100 & 40 & 40.32 & 100.8 & 0.236 & 0.585 & 0.136 \\
\hline & 120 & 44 & 44.18 & 100.4 & 0.102 & 0.231 & 0.059 \\
\hline \multirow{4}{*}{ Т 2} & 0 & 20 & 20.31 & 101.54 & 0.165 & 0.810 & 0.095 \\
\hline & 80 & 36 & 36.534 & 101.48 & 0.079 & 0.218 & 0.046 \\
\hline & 100 & 40 & 39.986 & 99.96 & 0.072 & 0.180 & 0.042 \\
\hline & 120 & 44 & 44.386 & 100.88 & 0.354 & 0.797 & 0.204 \\
\hline
\end{tabular}

T1, T2: (Cefigip, Taxim-O respectively); Acceptance criteria: \% RSD should be $<2$.

pharmaceutical formulations after spiking with additional drug at three different levels $(80 \%, 100 \%$ and $120 \%)$ afforded recovery of $99.96-101.54 \%$ for two formulations (Cefigip, Taxim-O), and mean recovery and \%RSD for cefixime trihydrate from marketed formulations are listed in Table III.

\section{Limit of detection (LOD) and limit of quantification (LOQ)}

From the linearity plot the LOD and LOQ of cefixime trihydrate were calculated by equation 1 and 2 respectively.

$$
\begin{aligned}
& \mathrm{LOD}=3.3 \sigma / \mathrm{S} \\
& \mathrm{LOQ}=10 \sigma / \mathrm{S}
\end{aligned}
$$

equation 1 equation 2

$\sigma=$ standard deviation of the response and $\mathrm{S}=$ slope of calibration curve; LOD and LOQ were found to be $0.0398 \mu \mathrm{g} / \mathrm{mL}$ and $0.120 \mu \mathrm{g} / \mathrm{mL}$ respectively which indicate adequate sensitivity of the method.

\section{Robustness}

In robustness study, each chromatographic factor selected was changed one by one to estimate the effect of change on the results. Thus, replicate injections $(n=3)$ of standard solution at three levels were performed with small changes in chromatographic parameters (factors). Results, presented in Table IV indicated that the selected parameters remained unaffected by the small variations in these factors. None of the alterations caused a significant change in peak area and tailing factor.

\section{System suitability}

The system suitability was established by evaluating parameters like theoretical plates, tailing factor, retention time and resolution. The results of system suitability shown in Table $\mathrm{V}$ proved that the method is suitable for intended purpose.

\section{CONCLUSION}

An economical stability-indicating HPLC method has been developed and validated for the determination of Cefixime trihydrate in API and in pharmaceutical formulations. The proposed method is accurate, precise, and specific and also has the ability to separate the drug from degradation products. The degradation products resulting from the forced degradation studies did not interfere with the detection of cefixime trihydrate. The concentration of drug was found to be changing from the initial concentration indicating that cefixime trihydrate undergoes degradation under different stress degradation conditions. 
TABLE IV - Robustness evaluation

\begin{tabular}{lccc}
\hline Parameter & Retention time & Area $(\mathbf{n}=\mathbf{3})$ & Tailing factor \\
\hline A. Flow Rate & & & \\
0.95 & 7.13 & 8625460 & 0.947 \\
1 & 6.81 & 8604812 & 0.931 \\
1.05 & 6.56 & 8662376 & 0.929 \\
Mean \pm SD & $6.83 \pm 0.286$ & $8630883 \pm 29162$ & $0.936 \pm 0.0098$ \\
\hline
\end{tabular}

\section{B. Percentage of Methanol in Mobile Phase}

\begin{tabular}{lccc}
24 & 7.31 & 8624025 & 0.926 \\
25 & 6.81 & 8604812 & 0.931 \\
26 & 6.34 & 8571749 & 0.931 \\
Mean \pm SD & $6.82 \pm 0.485$ & $8600195 \pm 26442$ & $0.929 \pm 0.0028$ \\
\hline
\end{tabular}

\section{C. pH of the Buffer}

\begin{tabular}{lccc}
6.1 & 6.82 & 8669663 & 0.932 \\
6.3 & 6.81 & 8604812 & 0.931 \\
6.5 & 6.74 & 8669386 & 0.941 \\
Mean \pm SD & $6.79 \pm 0.0436$ & $867954 \pm 37362$ & $0.935 \pm 0.0055$ \\
\hline D. Wavelength (nm) & & & \\
287 & 6.89 & 8602180 & 0.942 \\
289 & 6.81 & 8604812 & 0.931 \\
291 & 6.83 & 8569139 & 0.931 \\
Mean \pm SD & $6.84 \pm 0.042$ & $8592044 \pm 19879.63$ & $0.935 \pm 0.0063$ \\
\hline
\end{tabular}

TABLE V - System suitability parameters

\begin{tabular}{lcc}
\hline S.No. & Parameters & Value \\
\hline 1 & Retention time & 6.81 \\
2 & Theoretical plates & 3541 \\
3 & Tailing factor & 0.926 \\
4 & Resolution & $>2$ \\
5 & Capacity factor & 2.146 \\
\hline
\end{tabular}

\section{REFERENCES}

ARSHAD, H.M.; GAUHAR, S.; BANO, R.; MUHAMMAD, I.N. Development of HPLC-UV method for analysis of cefixime in raw materials and in capsule. Jordan J. Pharm. Sci., v.2, n.1, p.53-65, 2009.

ATTIMARAD, M.; ANROOP, B. Simultaneous determination of ofloxacin and cefixime by first and ratio first derivative UV spectrophotometry. Chron. Young Sci., v.2, n.3, p.144149, 2011.
BAKSHI, M.; SINGH, S. Development of validated stability indicating assay methods: critical review. J. Pharm. Biomed. Anal., v.28, n.6, p.1011-1040, 2002.

BEBAWY, L.I.; EL-KELANI, K.; FATTAH, L.A. Fluorimetric determination of some antibiotics in raw material and dosage forms through ternary complex formation with terbium $\left(\mathrm{Tb}^{3+}\right)$. J. Pharm. Biomed. Anal., v.32, n.6, p.12191225, 2003.

BROGDEN, R.N.; RICHARDS, D.M. Cefixime: a review of its antibacterial activity, pharmacokinetic properties and therapeutic potential. Drugs, v.38, n.4, p.524-550, 1989.

DHOKA, M.V.; SANDAGE, S.J.; DUMBRE, S.C. Simultaneous determination of cefixime trihydrate and dicloxacillin sodium in pharmaceutical dosage form by reversed-phase high-performance liquid chromatography. J. AOAC Int., v.93, n.2, p.531-535, 2010. 
EL-WALILY, A.F.M.; GAZY, A.A.; BELAL, S.F.; KHAMIS, E.F. Quantitative determination of some thiazole cephalosporins through complexation with palladium (II)chloride. J. Pharm. Biomed. Anal., v.22, n.2, p.385-392, 2002.

ERIC-JOVANOVIC, S.; AGBABA, D.; ZIVANOV-STAKIC, D.; VLADIMIROV, S. HPTLC determination of ceftriaxone, cefixime and cefotaxime in dosage forms. $J$. Pharm. Biomed. Anal., v.18, n.4/5, p.893-898, 1998.

GOLCU, A; DOGAN, B.; OZKAN, S.A. Anodic voltammetric behavior and determination of cefixime in pharmaceutical dosage forms and biological fluids. Talanta, v.67, n.4, p.703-712, 2005.

GONZALEZ-HERNANDEZ, R.; NUEVAS-PAZ, L.; SOTOMULET, L.; LOPEZ-LOPEZ, M.; HOOGMARTENS, J. Reversed phase high performance liquid chromatographic determination of cefixime in bulk drugs. J. Liq. Chromatogr. Relat. Technol., v.24, n.4, p.2315-2324, 2001.

INTERNATIONAL CONFERENCE ON HARMONIZATION. (ICH). International Conference on Harmonisation of technical requirements for registration of pharmaceuticals for human use. Quality Guidelines. Q2 Analytical Validation. Q2(R1). Validation of analytical procedures: text and methodology. ICH, 2005. 13p. Available at: $<$ http:// www.ich.org/fileadmin/Public Web Site/ICH Products/ Guidelines/Quality/Q2_R1/Step4/Q2_R1_Guideline. pdf $>$. Accessed on: Aug. 2014.

JAIN, R.; GUPTA, V.K.; JADON, N.; RADHAPYARI, K. Voltammetric determination of cefixime in pharmaceuticals and biological fluids. Anal. Biochem., v.407, n.1, p.79-88, 2010 .

KHANDAGLE, K.S.; GANDDHI, S.V.; DESHPANDE, P.B.; GAIKWAD, N.V. A simple and sensitive RPHPLC method for simultaneous estimation of cefixime and ofloxacin in combined tablet dosage form. Int. J. Pharm. Pharm. Sci., v.3, n.1, p.46-48, 2011.

KHAN, I.U.; SHARIF, S.; ASHFAQ, M.; ASGHAR, M.N. Simultaneous determination of potassium clavulanate and cefixime in synthetic mixtures by high performance liquid chromatography. J. AOAC. Int., v.91, n.4, p.744-749, 2008.
KITAMURA, S.; KODA, S.; MIYAMAE, A.; YASUDA, T.; MORIMOTO, Y. Dehydration effect on the stability of cefixime trihydrate. Int. J. Pharm., v.59, n.3, p.217-224, 1990.

MANNA, L.; VALVO, L. Development and validation of a fast reversed-phase ion-pairing liquid chromatographic method for simultaneous determination of eight cephalosporin antibiotics in pharmaceutical formulations. Chromatographia, v.60, n.11/12, p.645-649, 2004.

MENG, F.; CHEN, X.; ZENG, Y.; ZHONG, D. Sensitive liquid chromatography-tandem mass spectrometry method for the determination of cefixime in human plasma: application to a pharmacokinetic study. J. Chromatogr. B: Analyt. Technol. Biomed. Life Sci., v.819, n.2, p.277-282, 2005.

PAWAR, S.J.; KALE, A.P.; AMRUTKAR, M.P.; JAGADE, J.J.; PORE, N.S.; BHOSALE, A.V. HPTLC estimation of cefixime and cloxacillin in tablet dosage form. Asian J. Res. Chem., v.3, n.2, p.299-301, 2010.

SHAH, P.B.; PUNDARIKAKSHUDU, K. Spectrophotometric, difference spectroscopic, and high-performance liquid chromatographic methods for the determination of cefixime in pharmaceutical formulations. J. AOAC Int., v.89, n.4, p.987-994, 2006.

SINGH, D.K.; MAHESHWARI, G. Chromatographic studies of some cephalosporins on thin layers of silica gel G-zinc ferrocyanide. Biomed. Chromatogr, v.24, n.10, p.1084$1088,2010$.

SWEETMAN, S.C., ed. Martindale: the complete drug reference. 32.ed. London: Pharmaceutical Press, 1999. p.165-166.

TALEBPOUR, Z.; POURABDOLLAHI, H.; RAFATI, H.; ABDOLLAHPOUR, A.; BASHOUR, Y.; ABOUL-ENEIN, H.Y. Determination of cefixime by a validated stabilityindicating HPLC method and identification of its related substances by LC-MS/MS studies. Sci. Pharm., v.81, n.2, p.493-503, 2013.

Received for publication on $11^{\text {th }}$ August 2014. Accepted for publication on $12^{\text {th }}$ August 2015.

KITAMURA, S.; MIYAMAE, A.; KODA, S.; MORIMOTO, Y. Effect of grinding on the solid-state stability of cefixime trihydrate. Int. J. Pharm., v.56, n.2, p.125-134, 1989. 